\title{
Ultrastructural Alterations and Physical Changes on Bovine Dentin After Internal Bleaching with $35 \%$ Hydrogen Peroxide
}

\author{
Alteraciones Ultraestructurales y Cambios Físicos en la Dentina Bovina Después \\ del Blanqueamiento Interior con un $35 \%$ de Peróxido de Hidrógeno
}

\begin{abstract}
Micaele Maria Lopes Castro'; Maria Karolina Ferreira Martins'; Nathalia Carolina Fernandes Fagundes; Bárbara Catarina Lima Nogueira1; Tarsila Guimarães Vieira da Silva'; Fabio Reis de Oliveira'; Renata Duarte de Souza-Rodrigues ${ }^{2}$ \& Rafael Rodrigues Lima ${ }^{1}$
\end{abstract}

CASTRO, M. M. L.; MARTINS, M. K. F.; FAGUNDES, N. C. F.; NOGUEIRA, B. C. L.; DA SILVA, T. G. V.; DE OLIVEIRA, F. R.; DE SOUZA-RODRIGUES, R. D. \& LIMA, R. R. Ultrastructural alterations and physical changes on bovine dentin after internal bleaching with $35 \%$ hydrogen peroxide. Int. J. Odontostomat., 13(2):235-240, 2019.

ABSTRACT: The aim of the study was to investigate the effect of internal bleaching on physical proprieties and ultrastructure of the bovine dentin. 40 bovine incisors were used, divided in four experimental groups: control group, composed by teeth that did not receive the bleaching agent (G1); teeth submitted to a single internal bleaching session (G2); teeth submitted to two internal bleaching sessions (G3); teeth submitted to three internal bleaching sessions (G4). In each of the sessions, $35 \%$ hydrogen peroxide was applied for 45 minutes on the dentin surface. Tests were performed (microhardness and roughness) and were analyzed using one-way analysis of variance (ANOVA) and Tukey's post-hoc test ( $\leq 0.05$ ). Electromicrographs were captured for quality analysis. In the analysis of the superficial microhardness of the dentin, the internal bleaching reduced the Knoop microhardness since the first session, being observed statistically significant differences between the experimental groups and the control. The surface roughness gradually increased in the G2, G3 and G4 groups, but only G4 presented a statistically significant difference from the others. The qualitatively evaluated electromicrographs showed damage to the dentin ultrastructure, with areas of erosion and greater involvement of the intertubular when compared to peritubular dentin. Internal bleaching with $35 \%$ hydrogen peroxide caused injuries in bovine dentin from the first treatment session. Both modifications in physical properties and dentin ultrastructure have been identified. These changes were intensified the higher the number of dentin internal bleaching sessions was exposed.

KEY WORDS: dentin, internal bleaching, hydrogen peroxide.

\section{INTRODUCTION}

Internal dental bleaching is a conservative and cost-effective (Lee et al., 2004; Carrasco-Guerisoli et al., 2009; Zimmerli et al., 2010) method to improve esthetic outcomes. This technique represents an alternative to more invasive prosthondontic treatment of discolored non-vital teeth (Kiomarsi et al., 2018). The internal bleaching treatment it is useful because it is not an isolated treatment in the planning of patient care. The tooth that will receive the bleaching material will still undergo other procedures, which sometimes, not only depend on light transmission characteristics, but also on the color of the teeth that will be restored (Plotino et al., 2008).
The success of bleaching procedures is directly related to the ability of the whitening agent to affect the dentinal permeability. So, bleaching agents must have low molecular weight to penetrate enamel and dentin and remove pigments, either completely or partially (Carrasco et al., 2003; Kawamoto \& Tsujimoto, 2004).

One of the most commonly used bleaching agents is hydrogen peroxide $\left(\mathrm{H}_{2} \mathrm{O}_{2}\right)$ at concentrations of $30 \%$ a $35 \%$, which acts through the penetration into the dental structure and production of oxygen and hydroxyl free radical (OH-) (Plotino et al.; Zimmerli et

\footnotetext{
${ }^{1}$ Laboratory of Functional and Structural Biology, Institute of Biological Sciences, Federal University of Pará, Brazil.
}

${ }^{2}$ Institute of Art Sciences, Federal University of Pará, Brazil. 
CASTRO, M. M. L.; MARTINS, M. K. F.; FAGUNDES, N. C. F.; NOGUEIRA, B. C. L.; DA SILVA, T. G. V.; DE OLIVEIRA, F. R.; DE SOUZA-RODRIGUES, R. D. \& LIMA, R. R. Ultrastructural alterations and physical changes on bovine dentin after internal bleaching with $35 \%$ hydrogen peroxide. Int. J. Odontostomat., 13(2):235-240, 2019.

al.). Hydrogen peroxide is capable of oxidizing colored long-chain organic and inorganic components, causing de-coloration and bleaching of the substrate (Joiner, 2007).

Even though it is considered a low risk method (Zimmerli et al.), undesirable effects of whitening agents have been reported after internal bleaching on non-vital teeth (Chng et al., 2002, 2004, 2005; de Oliveira et al., 2007; Hannig et al., 2011). Thus, the purpose of this in vitro study was to investigate the physical proprieties and ultrastructure of the bovine dentin exposed to $35 \%$ hydrogen peroxide at each bleaching session.

\section{MATERIAL AND METHOD}

This study was approved by the Local Research Ethical Comitee (Protocol CEPAE-UFPA: BIO 013-09). Forty bovine incisors of approximately 36 months were used. Twenty teeth were used for physical property analysis (microhardness and roughness), while the other 20 were used for ultrastructural analysis of bovine dentin exposed to internal bleaching.

The teeth were debrided with periodontal curettes and immersed in $1 \%$ sodium hypochlorite solution during ten minutes to remove possible organic residues. After that, the teeth were washed thoroughly with distilled water in an ultrasonic bath for five minutes and stored at room temperature in distilled water until sample preparation.

Experimental Groups: The specimens were randomly divided into four groups, according to the number of bleaching sessions performed:

Group 1 (control, G1): teeth without bleaching; Group 2 (G2): teeth submitted to a single internal bleaching session;

Group 3 (G3): teeth submitted to two internal bleaching sessions;

Group 4 (G4): teeth submitted to three internal bleaching sessions.

Specimen Preparation: For each tooth, the middle portion of crown was ground with a water-cooled lowspeed handpiece in a mesiodistal direction in order to expose the coronary dentin that is closest to the dental pulp. Longitudinal sections allowed crown slabs measuring $4 \mathrm{~mm} \times 4 \mathrm{~mm} \times 2 \mathrm{~mm}$. The thickness of each slab was $2 \mathrm{~mm}$.
Internal Bleaching Technique: The groups were treated with Whiteness HP Maxx (35\% hydrogen peroxide, FGM Produtos Odontológicos, Joinville, SC, Brazil). The bleaching material was prepared following manufacturer's instructions: 1 drop of thickener for 3 drops of hydrogen peroxide until completely homogeneous.

Each bleaching session lasted 45 minutes. In G3 and G4, which had two and three sessions respectively, the interval between these was 7 days.

After the experimental procedures, bleaching products were removed by suction and washed thoroughly with distillated water. Between each session the specimens were immersed in distilled water at $37^{\circ} \mathrm{C}$ and stored in refrigeration. After 7 days of storage, the microhardness test and the scanning electron microscopy (SEM) analysis were performed.

Microhardness Test: For the analysis of microhardness and roughness, the specimens were embedded in autopolymerizable acrylic resin using polyvinyl chloride molds (20 mm diameter and $1.5 \mathrm{~cm}$ height), with the labial surface exposed for treatments.

The Knoop microhardness $(\mathrm{KNH})$ was performed using a microhardness testing machine (Future Tech FM 700 , Tokyo, Japan). For each specimen, five indentations were made by the same operator for 15 seconds with static load of $25 \mathrm{~g}$.

The measurement of average surface roughness (Ra) was performed using a mechanical rugosimeter (SJ301; Mitutoyo, California, USA). On each specimen, three measurements were performed at intervals of $5 \mathrm{~mm}$ and cut-off value of $0.25 \mathrm{~mm}$. The average of the three readings $(\mu \mathrm{m})$ was considered the average roughness of each surface.

Micromorphology analysis: For the SEM analysis, all specimens were immersed in $1 \%$ sodium hypochlorite $(\mathrm{NaClO})$ for five minutes, followed by washing with distilled water in an ultrasonic bath for 30 seconds. To remove any residual fragments, the specimens were immersed in EDTA for 10 seconds and washed again with distilled water in ultrasonic bath for 40 seconds.

After that, the specimens were dehydrated in ascending grades of ethanol series: $50 \%, 80 \%, 90 \%$ and $100 \%$ and air-dried at room temperature, Then, the specimens were mounted on stubs, coated with gold during $90 \mathrm{~s}$ and observed in scanning electron 


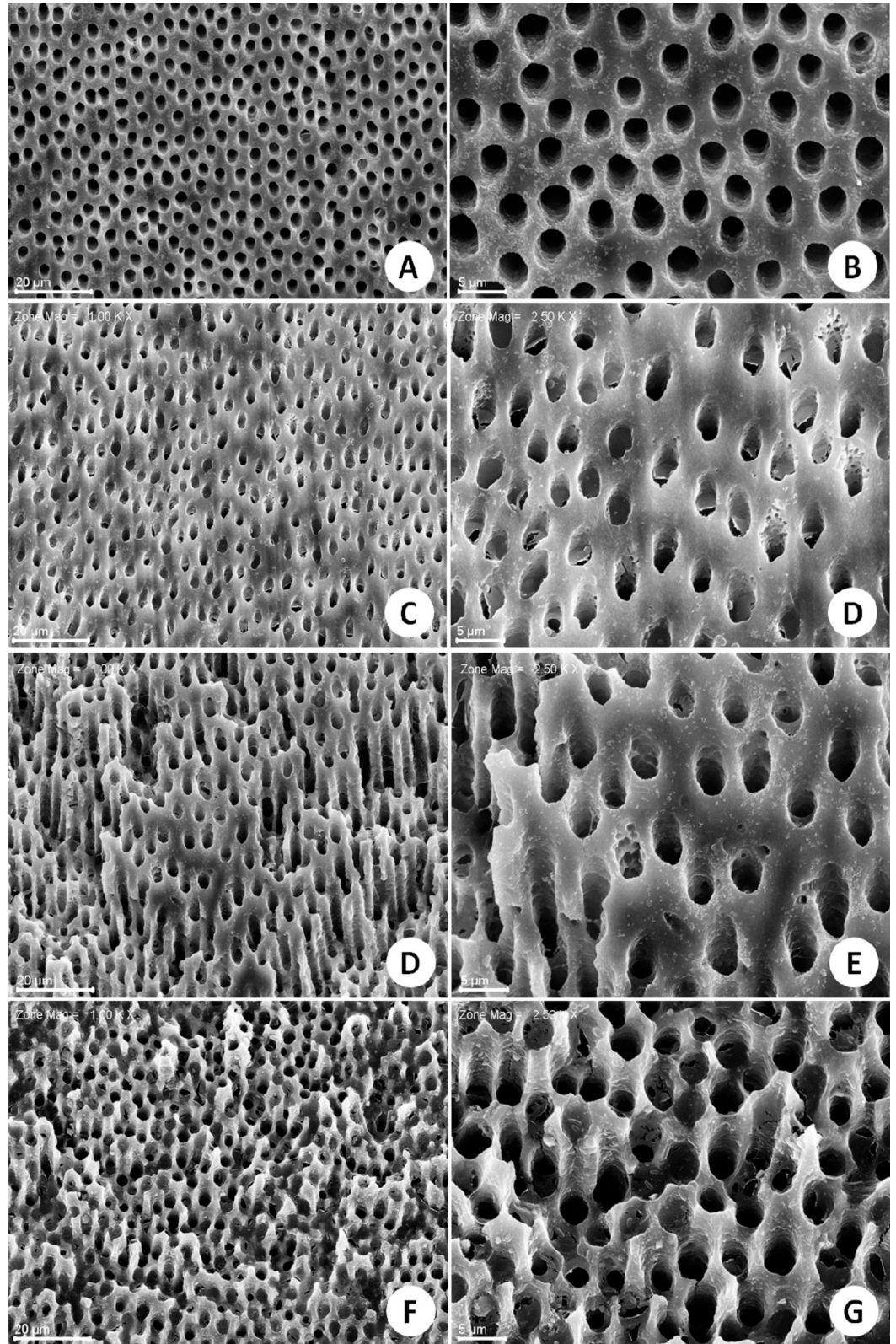

Fig. 1. Micromorphological aspects of bovine dentin in experimental groups. (A and B): Group 1: teeth without bleaching; (C and D): Group 2: teeth submitted to a single internal bleaching session; ( $E$ and F): Group 3: teeth submitted to two internal bleaching sessions; $(\mathrm{G}$ and $\mathrm{H})$ : teeth submitted to three internal bleaching sessions. microscope (LEO-1430 Carl Zeiss, Oberkochen, Germany). The electromicrographs were captured in two different magnifications (1000X and 2500X) and analyzed by a single assessor.

Statistical Analysis: The microhardness and roughness data were analyzed by Analysis of Variance (ANOVA), complemented with the Tukey post-hoc Test. The level of significance was $p \leq$ 0.05 . Statistical analyses of the data were performed using a Prisma 2.0 (San Diego, CA, USA). The electromicrographs were evaluated qualitatively.

\section{RESULTS}

Mean standard deviation (SD) values for the Knoop dentin microhardness $(\mathrm{KNH})$ of the tested groups are shown in Table I. There were statistically differences between mean KHN for treatment groups (G2, G3 and G4) and control group (G1). It was observed that the higher the number of internal bleaching sessions, the lower values of dentin microhardness were found.

The results of surface roughness (Ra) are presented in Table II. When compared to the control group, since the first session, all other groups submitted to internal bleaching presented increased dentin surface roughness. Comparing the experimental groups regarding the number of internal bleaching sessions, between $G 2$ and $G 3$ no statistical

Table I. Mean standard deviation (SD) values of the Knoop microhardness for bovine dentin after internal bleaching (KHN), according to the tested groups. Different letters indicate significant differences $(p \leq 0.05)$.

G1 G2

G3

G4

\begin{tabular}{llll}
\hline Mean standard deviation (SD) & $131.2 \mathrm{KHN} \pm 1.550^{\mathrm{a}}$ & $85.98 \mathrm{KHN} \pm 0.8883^{\mathrm{b}}$ & $76.85 \mathrm{KHN} \pm 0.9642 \mathrm{c}$
\end{tabular}

Table II. Mean standard deviation (SD) of surface roughness $(\mathrm{Ra})$ for bovine dentin after internal bleaching. Different letters indicate significant differences $(p \leq 0.05)$.

G1
G2
G3

G4

$\begin{array}{lllll}\text { Mean standard deviation (SD) } & 0.0608( \pm 0.0102)^{\mathrm{a}} & 0.0788( \pm 0.0091)^{\mathrm{b}} & 0.0809( \pm 0.0083)^{\mathrm{b}} & 0.1013( \pm 0.0026)^{\mathrm{C}}\end{array}$


CASTRO, M. M. L.; MARTINS, M. K. F.; FAGUNDES, N. C. F.; NOGUEIRA, B. C. L.; DA SILVA, T. G. V.; DE OLIVEIRA, F. R.; DE SOUZA-RODRIGUES, R. D. \& LIMA, R. R. Ultrastructural alterations and physical changes on bovine dentin after internal bleaching with $35 \%$ hydrogen peroxide. Int. J. Odontostomat., 13(2):235-240, 2019.

difference was observed. However, G4 presented increased surface roughness in comparison to the other groups.

Figure 1 illustrates the micromorphological aspects of bovine dentin in experimental groups. Different patterns of erosion were observed among them. Control group (Fig. 1A-B) presented no visible signs of dentin erosion. G2 (Fig. 1C-D) showed rough dentinal surfaces, with little or no erosion. G3 (Fig. 1EF) exhibited irregular surfaces with erosion, especially in intertubular dentin. In G4, constant eroded areas were produced on entire dentin. It was even possible to observe fusion between dentinal tubules. The depth of erosion was higher than any other groups.

\section{DISCUSSION}

Internal bleaching has promoted physical and ultrastructural damage to bovine dentin since the first treatment session. After the bleaching sessions, the dentin microhardness was progressively reduced and differences were observed between the tested groups. The surface roughness was increased after the first session, however only after the third session was observed a difference between the other groups. Ultrastructural changes were reported in all groups in which the bleaching agent was used. The greater number of internal bleaching sessions, these modifications have become more evident.

In the present study, bovine teeth were used to the purpose of standardization. Other previous studies have shown equivalent properties between bovine and human teet (Nakamichi et al., 1983; Attin et al., 2003; Camargo et al., 2008; Lopes et al., 2009). In the human teeth, the dentin has a larger diameter near the pulp and a smaller diameter near the amelodentin junction. In the bovine teeth, the diameter is larger near the amelodentin junction and smaller near the pulp (Lopes et al.). However, the physico-chemical characteristics of the bovine dentin do not differ considerably of human dentin (Hannig et al.), which justifies the use in situ of the bovine samples. In our study, the dentin samples evaluated were from the superficial vestibular region of the pulp chamber, so the morphological difference interferes minimally in the results.

Damage to dental structures after the internal bleaching technique has been reported previously. Other studies have demonstrated that teeth treated with hydrogen peroxide had lower microhardness values than groups were not treated with the bleaching agent (Chng et al., 2002, 2004, 2005; de Oliveira et al., 2015). Related results were found in our study, however the innovative differential we brought was the observation of dentin alterations in each session of the bleaching treatment, and not only at the end of the treatment. One of the explanations for this deleterious effect is that hydrogen peroxide diffusion dynamics seems to be determined by the chemical affinity between bleaching agent and the organic area of specific dental tissue (Ubaldini et al., 2013). Hydrogen peroxide showed a great deal of interaction with dentin, affecting only the inorganic components of this dental hard tissue through acidic demineralization, but also the relatively rich organic substance of the dentin by protein oxidation (Carrasco-Guerisoli et al.). Other explanation is that hydrogen peroxide generates free radicals that combines with hydroxyapatite, produces apatite peroxide and reduces the calcium-phosphate ratio (de Oliveira Moreira et al., 2015). That is an oxireduction reaction occurs between the bleaching agent and the substrate, which modifies the dyed molecule and alters some of characteristics, such as color (Plotino et al.).

Another study has reported structural alterations in dentin samples treated with the same bleaching system, Whiteness HP Maxx (Carrasco-Guerisoli et al.). The authors identified a dentin surface with little or no erosion at all and apparently intertubular was more affected than peritubular dentin. Although we used a different experimental model, we found similar results of dentin surface with little or no erosion for $\mathrm{G} 1$. One possible explanation for this result would be related to the $\mathrm{pH}$ of the bleaching agent, which in the case of the product used in our study, is alkaline and would be less aggressive to the dentin substrate when compared to other acidic $\mathrm{pH}$ agents (Carrasco-Guerisoli et al.). For groups G3 and G4, we found the dentin surface with greater areas of erosion than those reported in this other study, however we also observed that the intertubular dentine was more affected when compared to peritubular. One explanation for this result is that the peritubular dentine appeared to be more resistant to the oxidizing effects of hydrogen peroxide than intertubular dentine (Chng et al., 2005; Carrasco-Guerisoli et al.). Apparently, the resistance of these two types of dentin is related to the differences in their compositions. While the peritubular is hyper-mineralized and lacks collagen as an organic component of its matrix, a intertubular has a relatively high organic content and has as main component the collagen, which represents about 92 $\%$ of its composition (Chng et al., 2005). 


\section{CONCLUSION}

Considering the limitation of this in vitro study, internal bleaching with $35 \%$ hydrogen peroxide has caused injury to bovine dentin since the first treatment session. Throughout the bleaching sessions, dentin microhardness decreased, while surface roughness increased. In turn, the dentin ultrastructure presented irregular surface with areas of erosion and intertubular dentin being more affected than peritubular.

CASTRO, M. M. L.; MARTINS, M. K. F.; FAGUNDES, N. C. F.; NOGUEIRA, B. C. L.; DA SILVA, T. G. V.; DE OLIVEIRA, F. R.; DE SOUZA-RODRIGUES, R. D. \& LIMA, R. R. Alteraciones ultraestructurales y cambios físicos en la dentina bovina después del blanqueamiento interior con un $35 \%$ de peróxido de hidrógeno. Int. J. Odontostomat., 13(2) 235-240, 2019.

RESUMEN: El objetivo de este estudio fue investigar el efecto del blanqueamiento interno sobre las propiedades físicas y la ultraestructura de la dentina bovina. Se utilizaron 40 incisivos bovinos, divididos en cuatro grupos experimentales: grupo de control, compuesto por dientes que no recibieron el agente blanqueador (G1); dientes sometidos a una única sesión interna de blanqueamiento (G2); dientes sometidos a dos sesiones internas de blanqueamiento (G3); dientes sometidos a tres sesiones internas de blanqueamiento (G4). En cada una de las sesiones, se aplicó peróxido de hidrógeno al $35 \%$ durante 45 minutos en la superficie de la dentina. Se realizaron pruebas (microdureza y rugosidad). Los datos se analizaron mediante análisis de varianza de una vía (ANOVA) y prueba post-hoc de Tukey $(p \leq 0,05)$. Las electromicrografías fueron capturadas para el análisis cualitativo. En el análisis de la microdureza superficial de la dentina, el blanqueamiento interno redujo la microdureza de Knoop desde la primera sesión, observándose diferencias estadísticamente significativas entre los grupos experimentales y el control [NF2]. La rugosidad superficial aumentó gradualmente en los grupos G2, G3 y G4, pero solo G4 presentó una diferencia estadísticamente significativa con respecto a los otros [NF3]. Las electromicrografías evaluadas cualitativamente mostraron daño a la ultraestructura de la dentina, con áreas de erosión y una mayor participación de la dentina intertubular en comparación con la dentina peritubular. El blanqueamiento interno con peróxido de hidrógeno al $35 \%$ causó lesiones en la dentina bovina en la primera sesión del tratamiento. Ambas modificaciones, en propiedades físicas y en la ultraestructura dentinaria, han sido identificadas. Estos cambios se intensificaron a medida que se expuso a mayor número de sesiones de blanqueamiento interno en la dentina.

PALABRAS CLAVE: dentina, blanqueamiento interno, peróxido de hidrógeno.

\section{REFERENCES}

Attin, T.; Paqué, F.; Ajam, F. \& Lennon, A. M. Review of the current status of tooth whitening with the walking bleach technique. Int. Endod. J., 36(5):313-29, 2003.

Camargo, M. A.; Marques, M. M. \& de Cara, A. A. Morphological analysis of human and bovine dentine by scanning electron microscope investigation. Arch. Oral Biol., 53(2):105-8, 2008.

Carrasco-Guerisoli, L. D.; Schiavoni, R. J.; Barroso, J. M.; Guerisoli, D. M.; Pecora, J. D. \& Fröner, I. C. Effect of different bleaching systems on the ultrastructure of bovine dentin. Dent. Traumatol., 25(2):176-80, 2009.

Carrasco, L. D.; Fröner, I. C.; Corona, S. A. \& Pécora, J. D. Effect of internal bleaching agents on dentinal permeability of non-vital teeth: quantitative assessment. Dent. Traumatol., 19(2):85-9, 2003.

Chng, H. K.; Palamara, J. E. \& Messer, H. H. Effect of hydrogen peroxide and sodium perborate on biomechanical properties of human dentin. J. Endod., 28(2):62-7, 2002.

Chng, H. K.; Ramli, H. N.; Yapa, A. U. \& Limb, C. T. Effect of hydrogen peroxide on intertubular dentine. J. Dent., 33(5):363-9, 2005.

Chng, H. K.; Yap, A. U.; Wattanapayungkul, P. \& Sim, C. P. Effect of traditional and alternative intracoronal bleaching agents on microhardness of human dentine. J. Oral Rehabil., 31(8):811-6, 2004.

de Oliveira Moreira, P. E.; Pamplona, L. S.; Nascimento, G. C.; Esteves, R. A.; Pessoa, O. F. \& Silva, C. M. Effects of internal bleaching on the adhesion of glass-fiber posts. Open Dent. J., 9:375-9, 2015.

de Oliveira, D. P.; Teixeira, E. C.; Ferraz, C. C. \& Teixeira, F. B. Effect of intracoronal bleaching agents on dentin microhardness. J. Endod., 33(4):460-2, 2007.

Hannig, C.; Weinhold, H. C.; Becker, K. \& Attin, T. Diffusion of peroxides through dentine in vitro with and without prior use of a desensitizing varnish. Clin. Oral Investig., 15(6):863-8, 2011.

Joiner, A. Review of the effects of peroxide on enamel and dentine properties. J. Dent., 35(12):889-96, 2007.

Kawamoto, K. \& Tsujimoto, Y. Effects of the hydroxyl radical and hydrogen peroxide on tooth bleaching. J. Endod., 30(1):45-50, 2004.

Kiomarsi, N.; Arjmand, Y.; Kharrazi Fard, M. J. \& Chiniforush, $N$. Effects of erbium family laser on shear bond strength of composite to dentin after internal bleaching. J. Lasers Med. Sci., 9(1):58-62, 2018.

Lee, G. P.; Lee, M. Y.; Lum, S. O.; Poh, R. S. \& Lim, K. C. Extraradicular diffusion of hydrogen peroxide and $\mathrm{pH}$ changes associated with intracoronal bleaching of discoloured teeth using different bleaching agents. Int. Endod. J., 37(7):500-6, 2004.

Lopes, M. B.; Sinhoreti, M. A.; Gonini Júnior, A.; Consani, S. \& McCabe, J. F. Comparative study of tubular diameter and quantity for human and bovine dentin at different depths. Braz. Dent. J., 20(4):279-83, 2009. 
CASTRO, M. M. L.; MARTINS, M. K. F.; FAGUNDES, N. C. F.; NOGUEIRA, B. C. L.; DA SILVA, T. G. V.; DE OLIVEIRA, F. R.; DE SOUZA-RODRIGUES, R. D. \& LIMA, R. R. Ultrastructural alterations and physical changes on bovine dentin after internal bleaching with $35 \%$ hydrogen peroxide. Int. J. Odontostomat., 13(2):235-240, 2019.

Nakamichi, I.; Iwaku, M. \& Fusayama, T. Bovine teeth as possible substitutes in the adhesion test. J. Dent. Res., 62(10):1076-81, 1983

Plotino, G.; Buono, L.; Grande, N. M.; Pameijer, C. H. \& Somma, F. Nonvital tooth bleaching: a review of the literature and clinical procedures. J. Endod., 34(4):394407, 2008.

Ubaldini, A. L.; Baesso, M. L.; Medina Neto, A.; Sato, F.; Bento, A. C. \& Pascotto, R. C. Hydrogen peroxide diffusion dynamics in dental tissues. J. Dent. Res., 92(7):661-5, 2013.

Zimmerli, B.; Jeger, F. \& Lussi, A. Bleaching of nonvital teeth. A clinically relevant literature review. Schweiz. Monatsschr. Zahnmed., 120(4):306-20, 2010.
Corresponding author:

Rafael R. Lima, PhD

Laboratory of Functional and Structural Biology

Institute of Biological Science

Federal University of Pará

Belém PA

BRAZIL

Email: rafalima@ufpa.br

Received: 27-12-2018

Accepted: 25-02-2019 